Драгана Керкез

Универзитет у Београду

Филолошки факултет

Катедра за славистику

draganakerkez@hotmail.com
УДК 811.163.41'366.593

https://doi.org/10.18485/slavistika.2020.24.2.8

оригинални научни рад

примљено 18.07.2020.

прихваћено за штампу 18.09.2020.

\title{
НЕПРОТОТИПИЧНА УПОТРЕБА ИМПЕРАТИВНИХ ОБЛИКА У СРПСКОМ ЈЕЗИКУ
}

Предмет анализе у овом раду јесу пренесена значења императивних облика која се у постојећој литератури на српском језику подводе под приповедачки императив. На основу анализе структурно-семантичких разлика између појединачних транспозиционих употреба императивних облика аутор предлаже разликовање приповедачког, квалификативног, хабитуалног, адмиративног, деонтичког, концесивног и кондиционалог императива.

Кључне речи: пренесено значење, прошлост, приповедачки императив, структурно-семантички, лице, граматички број.

The subject of analysis in this paper is the transferred meanings of imperative forms which in the existing literature in the Serbian language are subsumed under the narrative imperative. Based on the analysis of structural-semantic differences between individual transpositional uses of imperative forms, the author proposes a distinction between the narrative, qualifying, habitual, admirative, deontic, concessional and conditional imperatives.

Keywords: transferred meaning, past, narrative imperative, structural-semantic, person, grammatical number.

0. А. Вежбицка у својој познатој студији «Семантические универсалии и описание языков» (Семантичке универзалије и дескрипщија језика, превод наш - Д.К.) примећује да, говорећи о императивној конструкцији, говоримо о посебној конструкцији помоћу које изражавамо следеће значење 'ја хоћу да ти нешто урадиш', те да, истина, постоје језици у којима дато значење није граматикализовано (о језицима без парадигме императива види нпр. Храковский 1992: 246-263), али да нису познати језици у којима се значење императивне конструкције не може исказати (Вежбицкая 1989: 49-50). ${ }^{1}$

Мотив молбе, захтева, према мишљењу америчког психолога Мајкла Томасела, основни је и најуочљивији од трију базних комуникативних мотива (Томаселло 2011: 86). ${ }^{2}$

${ }^{1}$ Став А. Вежбицке тешко да би ико могао оспорити, јер, уколико бисмо претпоставили да постоји језик чијим средствима није могуће вербализовати значење императивне конструције, претпоставили бисмо, заправо, да постоји језик којим човек не може изразити своју вољу, а воља је, како каже свети Јован Дамаскин, једно од најважнијих онтолошких својстава човека, тј. душе човекове (св. Јован Дамаскин 2006).

2 Доказ томе јесте и врло рана појава императива у говору деце. Како наводи С.Н. Цејтлин, облике $\partial а j, u д и$ дете почиње да употребљава још у периоду холофразе (Цейтлин 2000: 84). 
0.1. Граматикализација значења ‘ја хоћу да ти нешто урадиш’ својство је свих словенских језика, па тако и српског. ${ }^{3}$

На основу увида у постојеће граматике српског језика и радове посвећене императиву (види нпр. Стевановић 1989: 708-710; Пипер и др. 2013: 404-406; Станојчић и др. 1992: 387) видимо да се сва значења императивних облика обично подводе под један од следећих типова: императив за изражавање заповести, молбе и сл. (Знаш, мама, купи ми сатенску кошуљу, плаву, сећаш се какву сам имао прошле године (СК)), прохибитивни (Немојте више рећи ни речи (СК)), превентивни (Гледај да виђаш председника бар два пута у току дана, и једном ноћу (СК)), пословички (гномски) императив (Прво скочи, па онда реци $x o n)$, те приповедачки (наративни) императив (Ty се посваде и упири спроводник пушком и убије кнеза, и отале утеци (КЛ)).

Од свих наведених, предмет анализе у овом раду биће она значења императива која у српској граматичкој традицији имају заједнички именитељ - приповедачки а који представља тип непрототипичне, тј. неканонске употребе императивних облика. ${ }^{4}$

Емпиријску базу истраживања чине примери ексцерпирани из електронских корпуса српског језика (СК, КЛ), дигиталне едиције Антологија српске књижевности (АСК), као и неких других електронских извора.

1. Полисемичност императивних облика карактеристика је многих језика, међу њима и српског, што, наравно, није остало незабележно у лингвистичкој литератури (Стојановић 1921; Пешикан 1956; Томановић 1962; Стевановић 1971; Јањушевић 2005; Князев 2007). Међутим, како се нама чини, многа питања везана за дати језички феномен остала су отворена. Између осталог, такво је питање семантичког обима термина приповедачки императив.

Увид у литературу на дату тему омогућује да се већ на први поглед уоче три чињенице.

Прва - сфера употребе приповедачког императива ${ }^{5}$ у српском језику веома је широка. Уколико упоредимо семантику императивних облика у примерима који следе (примери 1 и 2) врло ћемо лако уочити разлику: док у првом примеру можемо говорити о употреби императива са циљем истицања интензитета радње, у другом случају се помоћу императивног облика означава радња која се редовно понављала.

1. Кад то она чује, отиде, па вуци камен, те опет девет година ради она у камену, а нигдје нитко не умире, већ има стараца и болесника који моле бога

\footnotetext{
${ }^{3}$ Међутим, оно што српски и друге јужнословенске језике, а поред њих и руски, издваја из општесловенског корпуса јесте чињеница да је у јужнословенским језицима и руском језику присутна двочлана парадигма синтетичког императива, за разлику од западнословенских, те украјинског и белоруског језика где имамо трочлану парадигму. Нпр. наспрам Хajme да му помогнемо у српском, тј. Давайте поможем ему у руском језику, у чешком имамо Ротоzте ти (Манучарян 2015: 180).

${ }^{4}$ Као непрототипичне ми видимо све употребе императивног облика у којима посматрани облик на овај или онај начин мења своје категоријално парадигматско значење и синтаксичко окружење (уп. Храковский и др. 2001: 226).

${ }^{5}$ Поред термина приповедачки или наративни среће се и термин историјски императив.
} 
дан и ноћ да умру, али да: гдје је смрт? [ $\rightarrow$... па је потом свом снагом (интензивно) вукла камен, ...](СрпНП_АСК)

2. Србији треба тиранин, каква демократија. Душан је био прави вођа за Србију, кад украде, а он руку па сеци на пањ $[\rightarrow \ldots$ сваки пут кад неко нешто украде, Душан му руку стави на пањ и одсече] (КЛ).

Друга - могућност употребе императива као маркера неочекиваности остаје углавном непримећена. ${ }^{6}$

Трећа - приповедачки императив се у српском језику претежно, али не искључиво, везује за дијалекте (види нпр. Пешикан 1956) или се карактерише као граматички архаизам (види нпр. Пипер и др. 2013: 406). ${ }^{7}$

Ми ћемо у свом раду покушати потврдити следеће радне хипотезе:

- није сасвим оправдано једним термином обухватити различите непрототипичне употребе императивних облика;

- $\quad$ императивним обликом се у у српском може указати на неочекиваност ситуације која је била актуелна у одређеном тренутку;

- $\quad$ непрототипична употреба императивних облика није облигаторно везана за означавање прошлих радњи.

\section{1 Прототипични императив и пренесена значења императивних облика}

Дакле, будући да императивном конструкцијом говорно лице изражава своју вољу, канонски (прототипични) императив, како бележи и литература, увек претпоставља субјекта говорног чина, Прескриптора, потом субјекта каузиране радње, тј. онога коме је прескрипција упућена или Адресата, те саму Прескрипцију.

Међутим, слажући се око инваријантног значења императивне конструкције, као и њене полисемичности, граматичари заузимају различита гледишта када је реч о семантичкој струкутри прототипичних и непрототипичних употреба императивне конструкције.

Е. Фортејн бележи да постоје два основна погледа на проблематику значења императива: моносемични (све употребе императива представљају реализацију једног заједничког значења) и полисемични (транспозиционо употребљени, императивни облици губе своју императивну семантику) и као представнике овог другог приступа наводи Храковског и Володина (Фортейн 2008: 2).

\footnotetext{
${ }^{6}$ Истини за вољу, може се рећи да својеврсан изузетак у том погледу чини А. Јањушевић у чијем магистарском раду Форме са императивним значењем у савременом српском језику читамо: «Приповједачким императивом у српском језику обично (истииање је наше - Д.К.) се не исказују радње које су се изненада десиле. Уколико је потребно назначити да се нешто десило изненада, обично ће приповједач употријебити узвик (Јањушевић 2005: 76).

${ }^{7}$ Нпр.у граматици М. Миновића у делу текста посвећеном приповедачком императиву читамо «U savremenoj pripovjedačkoj prozi nije frekventan, a ima ga posebno kod onih pisaca koji u svome pripovjedanju iskorišćuju osobine narodnog govora (Minović 1987: 177). Исто тако, у Синтакси српског језика. Проста реченииа употребе императива за означавање радње која се понављала у прошлости у делима савремених писаца се не одриче, већ се одређује као мање карактеристична, будући да се у тој функцији у савременом српском језику чешће јавља потенцијал (Танасић 2005: 457).
} 
Заправо, постоји и трећи пут (уп. Гусев 2013: 20) - управо онај који предлажу Храковски и Володин уводећи дистинкцију између унутарпарадигматских и непарадигматских транспозиционих значења императива. За разлику од непарадигматских транспозиционих значења императива, парадигматски транспозиционо употребљени императивни облици чувају општекатегоријално значење изражавања воље (у широком смислу речи), али мењају значење категорије лица и/или добијају додатна значења која нису својствена императивном облику у „канонском“ контексту, што, најчешће, прати и промена непосредног синтаксичког окружења (Храковский, Володин 2001: 227).

Непарадигматски транспозиционо употребљени императивни облици губе категоријално значење изражавања воље. Наравно, мења се и семантичка структура овако употребљених императивних конструкција.

2. Приповедачки императив у српском језику се, као што смо већ споменули, одређује као језичко средство „за експресивно означавање радњй која се вршила или извршила у прошлости“ (Пипер и др. 2013: 404; уп. нпр. Стојановић 1921: 196-197; Стевановић 1989: 709).

Међутим, на основу анализе емпиријског материјала дошли смо до закључка да императивни облици који се сврставају под приповедачки императив могу вршити и функцију маркера радње које нису претеритално или темпорално маркиране. ${ }^{8}$

Тачније, сва пренесена значења императивних облика која се српској граматичкој традицији одређују као приповедачки императив могли бисмо поделити на две групе. Прву групу чинила би значења маркирана у односу на критеријум ‘претериталност' (пренесена значења императивних облика са обавезном претериталном семантиком), док би другу групу чинила значења која су према датом критеријуму немаркирана.

2.1 Пренесена значења императивних облика са обавезном претериталном семантиком.

У ову групу издвојили смо императивне облике који указују на радњу која је била актуелна у прошлости и ...

- $\quad$ поседује додатни ефекат посведочености, доживљености радње (приповедачки императив);

- издваја се својим интензитетом (квалификативни императив);

- циклично се понављала (хабитуални илператив);

- $\quad$ која је била неочекивана (адмиративни императив).

2.1.1 Приповедачки, квалификативни и хабитуални императив

На способност српског језика да се радње које су биле актуелне у прошлости искажу императивом указао је, између осталих, пре безмало сто година Љ.

${ }^{8}$ У том смислу наш закључак је само условно опречан мишљењу да се пренесено употребљеним императивним облицима могу вербализовати једино прошле радње: „Императив се сврстава међу глаголске облике који су подложни временском транспоновању. Транспоновање императива могуће је само у прошлост, никако у будућност (Пипер и др. 2005: 456)“. 
Стојановић (Стојановић 1921: 196-197) и своју тврдњу илустровао примерима међу којима су и следећи:

\section{3. Ја реци, а они ухвати па изврни.}

4. Она скиде с руке своју плетивачу, а ми с коњ своје вреће, па пуни и мјери, док напунисмо вреће за све тридесет коња.

Премда је несумњиво да се у свим наведеним примерима императивним облицима бележи радња која је била актуелна у прошлости, они се међусобно разликују: за разлику од императивних облика употребљених у примеру 3 , императивни облици у примеру 4, по нашем мишљењу, имају функцију маркера интензитета радње.

У првом примеру преузетом из рада Љ. Стојановића (пример 3) императивни облици маркирају сукцесивне, узрочно-последично повезане радње које су се одиграле у прошлости. Употребом императивних облика говорно лице појачава ефекат посведочености, доживљености радње и аутентичности догађаја (Вељовић и др. 2017: 51). При томе, као што видимо из примера 3, ове радње може вршити више лица, но напоредност предикативних основа ${ }^{9}$ није обавезна.

Приповедачи императив препознајемо и у следећим примерима:

5. Те ја узми троструку канцију, ужсени јој у месо кошљу: враг утече некуд без обзира, а оздрави снаха Анђелија... (ППњ_ГВ_АСК)

6. ... па у Дугу с четом западнули, дочекали карван од Никиићах; покољи се на друм са Турцима, четрнаест посјеци Тураках и узми им седамдесет коюах и двије три ухвати робиње. (ППЬ_ГВ_АСК)

7. ... а одовуд неки од натијех, умимогред, покрај оче мини и тисни му од лакта рожину његовојзи у грлић иишани. (ППњ_ГВ_АСК)

8. Ту се посваде и упри спроводник пушком и убије кнеза, и отале он утеци. (КЛ)

Управо овакву употребу императивних облика ми видимо као прави приповедачки императив чије бисмо инваријантно значење могли представити на следећи начин: 'говорно лице сигнализира да је до актуализације ситуације $\mathrm{S}_{1}$ $\left(\mathrm{S}_{2}, \ldots\right)$ дошло у трентуку $\left.\mathrm{t}_{1} \mathrm{t}_{2}, \ldots\right)$; тренутак $\left.\mathrm{t}_{1} \mathrm{t}_{2}, \ldots\right)$ претходи моменту говора'.

Напоредно са императивом често имамо употребљене и друге претериталне облике. Најчешће конкурентно средство је аорист.

9. У тај час нестане и трговине и купиа, него од трговине створи се голуб, а од Турчина створи се кобац, па потерај голуба! (СрпНП_АСК)

Наш емпиријски материјал показује да се у конструкцијама овог типа императивни облик глагола свршеног вида чешће среће него императивни облик глагола несвршеног вида. Вршилац радње може бити изражен именичком (оба граматичка броја) или заменичком речју (1. и 3. лице једнине и множине), у зависности од тога да ли је вршилац радње једно или више лица.

Понекад, што је заправо честа појава у језику, имамо кумулативно изражавање радњи које су се одвијале у одређеном временском следу са наглашеним интенизтетом;

\footnotetext{
${ }^{9}$ Овде је важно рећи да ми, следећи у томе велики број руских граматичара, реченицу у којој се за један граматички субјекат везује више предикатских израза не сматрамо сложеном.
} 
10. Докопа ти оно чаканац, па онако лудо и пијано - све поскочи и удри што може више у бубањ. (Глиш_АСК)

11. Свуд је води по манастирима и чита' јој масла и бденија; куми врага у све манастире да остави снаху Анђелију, куми врага - ништа не помаже! (ППњ_ГВ_АСК)

На то да се императивним обликом може вербализовати и психички и/ или физички интензитет прошле радње указао је у своје време В. Томановић издвојивши напрегнутост као главну одлику приповедачког императива (Томановић 1963: 227-228). ${ }^{10}$ Будући да помоћу императивног облика говорно лице описује, детерминише начин вршења одређење радње, за овакву његову употребу предлажемо термин квалификативни императив ('говорно лице сигнализира да се током временског периода, који је претходио моменту говора, актуализација ситуације $\mathrm{S}_{1}$ одвијала наглашеним интензитетом').

12. Онда ова двојица брже вуци сламу, па турај у онујазбину, па онда запале, и тако сва три змаја онде пропадну (СрпНП_АСК).

Врло често семантика интензитета се постиже редупликацијом облика:

13. Има и право дјечак! - гракну Николетина. - Данас те туче овај, сутра онај, удри, удри, док најзад не заборавиш да си човјек. У вола се претвориш. (ОрлЋоп_ACK)

14. Онда он копај, копај, те ископа и осталијех шест казана. (СрпНП_АСК)

15. Они вуци, вуци, па кад довукли до половице, пусте и уже и камен, те камен буб доље. (СрпНП_АСК)

За разлику од приповедачког, квалификативни императив се твори претежно од глагола несвршеног вила. Иако не постоји никаква формална препрека да вршилац радње буде изражен обликом 1. лица једнине или множине, у свим примерима које смо пронашли у корпусу субјекат има форму 3. лица једнине или множине.

Када је реч о квалификативном императиву посебно занимљиве јесу колокације са глаголом 'ударити' у императиву + императив неког другог глагола, у којима облик 'удри’ врши функцију интензификатора:

16. А они и једни и други удри фали сваки своју,... а он се само окреће час једној, час другој. (ПопСр_АСК)

17. Опет они удри риљај још једно пола сата. (СК)

Термин квалификативни императив већ је у употреби, но он се традиционално користи за именовање радњи које су се у прошлости понављале по неком реду или обичају, навици:

18. Милић никад није казивао шта намерава, већ кад му падне напамет заврзи се својом верном латинком, на кукуљи струку, запали чибук, па крен и лагано (пример преузет из Стевановић 1989: 101).

10 „Ова напрегнутост је и физичка и психичка, јер се при раду напрежу и мускули и воља и пажња, а осим тога често је праћен јачом или слабијом емоцијом, афектом, па се овим глаголским обликом исказују и ова психичка стања““ (Томановић, нав. дело). 
19. Пре рата никако нису летовали у граду, него како наиђи лето, они ти лепо набави огрев за зиму (пример преузет из Стевановић 1972: 709). ${ }^{11}$

Примери из радова М. Стевановића, с наше тачке гледишта, потпадали би под хабитуални императив. ${ }^{12}$ Значење хабитуалног императива ('говорно лице сигнализира да је у прошлости након актуализације ситуације $S_{1}$ сваког пута следила актуализација ситуације $\mathrm{S}_{2}{ }^{\prime}$ ) реализује се примеру бр. 2 као и у следећим примерима:

20. Онда их черече, па тражирају, ту на лииу места, черече и виле и вилењаке, па трпај у гепек, и разлаз кућама, свако са својим злочином. (КЛ)

21. Па ми је исто један из Буковиче приповиједао, да је у њега била крава отелила се, кад свако подне стани је рика те утеци и заштркьај се низ поље, па у огреду. (КЛ)

У свим наведеним примерима имамо ситуације које су у одређеним околностима у току дужег временског периода постајале актуелне (уп. Шлуинский 2005: 87), ${ }^{13}$ стога је радња исказана хабитуалним императивом узрочно-последично повезна са радњом која јој претходи. ${ }^{14}$ Другим речима, имамо две ситуације: једну која условљава и другу која је условљена, чинећи заједно једну интегративну биситутивну смисаону целину (уп. Евтюхин 1996: 141).

Најчешће радња која претходи и условљава није исказана хабитуалним императивом. Међутим, пример који Б. Вељовић наводи из приповетке Ћ. Сирајића потврђује да хабитуални императив може стајати како у условљавајућем, тако и у условљеном делу итеративне конструкције: On ženu dovedi, a ja je odvedi (Вељовић 2017: 55). Овај пример је занимљив још из једног разлога: иако хабитуални императив углавном стоји уз 3. лице, очигледно да вршилац радње може бити формализован и 1 . лицем.

В. Томановић запажа да хабитуални императив обично стоји после потенцијала, који је, заједно са перфектом имперфективних глагола, један од глаголских облика којима се у српском језику може вербализовати понављање радње: Свако јутро кад би дан свануо, излазило б’ двоје Ђеие лудо на ливаду под Бурову кулу, пак би сјели на зелену траву те сузама травии заљевај (Томановић 1963: 229).

${ }^{11}$ Као илустрацију квалификативног императива исти пример, али нешто измењен (него како наићи лето, она ти лепо набави огрев за зиму), налазимо и у раду Софије РакићМилојковић (Ракић-Милојковић 1995: 558).

${ }^{12}$ Веза између хабитуалности и квалификативности је несумњива: уколико се учешће X-a у ситуацији $\mathrm{S}$ понаваља са одређеном закономерношћу, можемо рећи је за X-а карактеристично учешће у ситуацији S (уп. Шлуинский 2005: 83; Вељовић 2017: 48).

${ }^{13}$ В.С. Храковски итеративне конструкције овог типа назива узуативима: „Ситуации, входящие в итеративное множесто могут специально характеризоваться как осуществляющиеся в соответствии с какой-либо эмпирически наблюдаемой вероятностной закономерностью. В этом случае принято говорить об узитативном значении (Храковский 1989: 49).

${ }_{14}$ Дакле, и овде, као и у примерима које анализира Т. Ашић у раду посвећеном потенцијалу као средству за означавање понављања у прошлости, можемо говорити о условљеној хабитуалности (Ашић 2006: 144). 
Неоспорна је чињеница да се хабитуални императив, у односу на друга два конкурентна средства, ређе среће у савременом српском језику. Ипак, поставља се питање у каквом је односу са њима.

Пишући на тему овремењавања прошлих радњи, М. Ивић запажа да српски језик припада језицима за које је дистинкција „евокативно“ / „фактографско“ релевантна. У првом случају користиће се потенцијал, док ће се перфекту прибећи уколико се о радњама понављаним у прошлости говори фактографски (Ивић 1995: 44).

Хабитуални императив се може, мишљења смо, употребити само уколико евоцирамо радње понављане у прошлости. ${ }^{15}$ Користећи хабитуални императив наратор свој исказ чини експресивно маркираним, а своју нарацију динамичнијом.

Као што се из наведених примера може видети, хабитуални императив нема ограничења када је категорија вида у питању. Вршилац радње је најчешће изражен трећим лицем, но, уколико није формално исказан, може имати уопштенолично значење:

22. Знам - чувао си козе овдје. Овце и козе и говеда, све заједно помијешај да пландује ту око Градине, па намузи у стамбурак до миле воље. (пример преузет из Јањушевић 2005).

\subsection{2 Адмиративни императив}

Већ смо споменули чињеницу да је В. Томановић као основно значење приповедачког императива препознавао значење напрегнутости, која може бити и психичка: „Психичка напетост која се исказује овом формом не односи се само на радно лице него и на говорно: зато што оно преживљује догађај о којему прича и саосећа са оним што доживљује радно лице. Пошто психичка напетост говорног лица може настати не само због рада лица о којему говори, него и због било каквог догађаја о којему оно приповеда, овом формом се исказује и тако настала психичка напетост (...)», те се даље наводе примери међу којима је и следећи из Горског вијенцза П.П. Његоша: У то рикни низ пазар ријека, након чега Томановић упућује на чињеницу да идентична ситуација постоји и у руском језику (Положил я его на стол, чтобы ему операцию, делать, а он возьми и умри 16 у меня под хлороформом) (Томановић 1963: 228).

Заиста, и у примеру из Његошевог Горског вијения као и у примеру из руског језика императивни облици имају исту семнатику, будући да се помоћу императивних облика у наведним примерима, по нашем мишљењу, вербализује неочекиваност. Маркирање неочекиваности препознајемо и у наредном примеру који бисмо могли парафразирати на следећи начин: 'говорно лице каже да су X-a

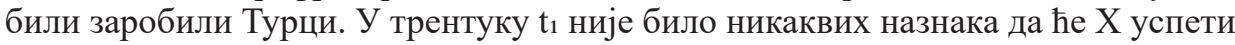
да се ослободи турског ропства. У тренутку $\mathrm{t}_{2} \mathrm{X}$ се ослободио турског ропства':

\section{3. А онда ти он утеци Турц̧има. (СРБ_У)}

${ }^{15}$ Ово објашњава због чега се хабитуални императив може срести у оквиру истог исказа у ком је у истој функцији употребљен потенцијал, а не и перфекат.

${ }^{16} \mathrm{O}$ конструкцији взять и сделать у руском језику (која представља један од подтипова тзв. «осложњеног» предиката) види нпр. Шведова 1980: 221 -222; Добровольский и др. 2018. 
И овде, као и у примеру 24, одабиром императивног облика у функцији маркера неочекиваности актуализације одређене ситуције говорно лице свој исказ експресивно маркира, а самим тим га чини динамичнијим, тј. фокализује га (уп. Ашић 2006: 147):

24. Скочи једно јутро народ, истерај га, а мене постави за кмета (Стевановић 1989: 708)

Да акценат није на начину вршења радње, већ на неочекиваности догађаја показује нам концепт ${ }^{17}$ адмиративног императива који подразумева:

- ситуацију S која је постала актуелна у одређеном тренутку;

- својство те ситуације, тј. учесника са семантичком улогом 'Својство';

- оног који тај догађај перцепира, тј. учесника са семантичком улогом 'Експеријенсер';

- оног који је каузирао актуелност ситуације $\mathrm{S}, \mathrm{rj}$. учесника са семантичком улогом 'Каузатор'.

Када говоримо о адмиративном императиву, посебно место заузима конструкција Дај не причај! у ситуацијама када говорно лице саопштава свом саговорнику да је од њега чуо нешто што одступа од очекиваног.

До сада се, као што смо већ поменули напред у тексту (напомена 6), транспоновани императивни облик ретко препознавао као средство маркирања неочекиваности. Међутим, нама се чини да императив перфективних глагола у српском језику, уз субјекат формализован 1. и 3. лицем оба граматичка броја, поседује такав транспозициони потенцијал ('говорно лице сигнализира да је у тренутку $\mathrm{t}$ дошло до неочекиване актулизације ситуације S').

Истина, адмиративни императив се среће веома ретко, будући да се у овој функцији налази у синтаксичко-семантичкој опозицији са аористом, који је, без сваке сумње, далеко чешћи у позицији маркера неочекиваности. ${ }^{18}$

2.2 Пренесена значења императивних облика са необавезном претериталном семантиком

У ову групу издвојили смо императивне облике који указују на радњу која није претеритално или временски маркирана и ...

- чија актуализација противуречи супротстављеној јој ситуацији (конщесивни илператив);

- чију актуализацију говорно лице карактерише као наметнуту (деонитички императив);

- чију је актуализацију условила актуализација неке друге ситуације (кондиционални императив).

17 «Глагольная лексема, будучи употреблена в высказывании, описывает некую с и туац и ю. Тем самым лексема (или говорящий с помощью данной лексемы) ко н цеп ту а л и зу ет определенный фрагмент внеязыковой действительности, сопоставляя ему нечто, что можно назвать "концепт ситуации", и этот концепт включает определенный набор участников» (Падучева 2004: 52).

18 Аорист као маркер неочекиваности у српском језику већ је био предмет наше пажње (Керкез 2012). 


\subsection{1 Концесивни императив}

Супротстављање двеју ситуација карактеристично је и за реченице са концесивним императивом чије инваријантно значење можемо представити на следећи начин: 'актуелност ситуације $\mathrm{S}_{1}$ имплицира неактуелност ситуције $\mathrm{S}_{2}$; говорно лице констатује актуелност ситуације $\mathrm{S}_{1}$ без обзира на то што је актуелна ситуација $\mathrm{S}_{2}$ ':

25. (...) и кад треба да се попне на ту планину воз једноставно неће да крене; куми, моли, купуј котлове, анрацит и лигнит, али не вреди .... (КЛ)

Клауза са концесивним императивом често се уводи редуплицираном партикулом-везником ${ }^{19} u$ који врши функцију интензификатора:

26. Живка: Jy, није да цепа, тетка, него дере као вук јагњећу кожу. И купуј, и прекрајај му, никад ништа на юему иело ни двадесет четири сата. (Нуш_ ГM_ACK)

Осим значења концесивности ситуација $\mathrm{S}_{1}$ може истовремено (кумулативно) реализовати хабитуално значење. Семантички близак концесивном је и адмиративни императив, ${ }^{20}$ но за разлику од њих концесивни императив није обавезно претеритално маркиран и образује се само од глагола несвршеног вида.

Као што из наведених примера можемо видети концесивни императив се гради од имперфективних глагола, а субјекат радње на површинском граматичком нивоу није експлициран.

\subsection{2 Деонтички императив ${ }^{21}$}

Деонтички императив ('говорно лице сигнализира да му се актуализација ситуације $S$ намеће') среће се у адверзативним реченицама у којима се ситуацији $\mathrm{S}_{1}$ која не зависи од говорног лица (фонска ситуација у терминологији Добрушине (Добрушина 2016:131)) супротставља ситуација $\mathrm{S}_{2}$ чији је агенс говорно лице. Актуализацију ситуације $\mathrm{S}_{2}$ говорно лице доживљава као одређену врсту присиле, те према томе има негативан став (уп. Храковский, Володин 2001: 237; Перцов 2001: 216). ${ }^{22}$ Семантички акценат је управо на негатив-

${ }^{19}$ Подробније о партикули-везнику $и$ види нпр. Јањушевић 2018.

20 Значење концесивности се често интерпретира као значење изневереног очекивања, што би било тешко оспорити. Међутим, ми смо такође и мишљења да се између концесивности и неочекиваности не може ставити знак једнакости, на чему се овде, узимајући у обзир дозвољени обим рада, нећемо заустављати.

${ }^{21}$ Термин који предлажемо одабрали смо руководећи се руском литературом у којој се међу непрототипичним употребама императивних облика издваја и императив «со значением реализуемого долженствования» (види нпр. Храковский и др. 2001: 238; Перцов 216), као и термин «императив долженствования» (види нпр. Добрушина 2016: 130).

При томе, свесни смо повезаности прототипично употребљеног императива и деонтичке модалности: «Включение смысла 'долженствование' в конотации императива связано с тем, что, хотя этот смысл и не вытекает со строгой необходимостью из смысла 'побуждение' (если X побуждает Y к Z-y, из того не следеут, что Y должен делать Z), все же соответствующая модальность высоко вероятна при выражении побуждения - ср. близкий к модальности долженствования смысл прогноза будущего действия адресата»( Перцов 2001: $210-211)$.

\footnotetext{
${ }^{22}$ Осим тога, деонтички императив може реализовати значење наглашеног облигатива, тј.
} 
ном ставу говорног лица према актуализацији ситуације $\mathrm{S}_{2}$, тј. на односу говорног лица према ситуацији $\mathrm{S}_{2}$, док је сама ситуација негде у другом плану. Ситуације $\mathrm{S}_{1}$ и $\mathrm{S}_{2}$ могу, али не морају бити међусобно на одређени начин логички условљене:

27. Сва деца се играју у дворишту, а ти Марија седи у кући и учи (из личне картотеке).

У функцији деонтичког срећу се само императивни облици имперфективних глагола. Агенс ситуације $S_{1}$ може бити било које лице осим говорног, док je носилац функције агенса ситуације $S_{2}$ управо говорно лице (уп. Храковский и др. 2001: 237), које у односу на себе користи заменицу 2. лица. ${ }^{23}$ После заменице следи именица у вокативу која са заменицом чини једну интонацијску и значењску целину:

28. Sve uredno i po zakonu, a ti gradjanine plaćaj. (Југпрес)

Деонтички императив убрајамо у непрототипичне употребе императивних облика будући да, тако употребљен, императив губи своје парадигматско значење 2. лица: у првом предикацијском делу изражена је објективна радња која не зависи од воље говорног лица (Сва деца се играју у дворишту), док у другом предикацијском делу деонтичким императивом говорно лице обликом 2. лица једнине изражава свој негативан став према радњи која му је наметнута (... а ти Марија седи у кући и учи).

\subsection{3 Кондиционални императив}

Кондиционални императив се среће у асиндентским сложеним реченицама корелативним са условним зависносложеним реченицама:

29. (...) укради патике или панталоне у продавници, добићеш годину дана, отми неком 500 динара, добићеш три до пет година затвора, ... [ $\rightarrow$ Ако украдеш патике или панталоне у продавници, добићеш годину дана, ако отмеш неком 500 динара, добићеш три до пет година затвора](КЛ).

30. Њему дај један прст, узеће ти изелу шаку. ${ }^{24}$ (из личне картотеке)

31. Молитва је постала свакодневни пратилаи. Тражи и наћи ћеш. Куцај и omвориће се". (КЛ $)^{25}$

њиме се може означити ситуација која се намеће али која неће бити извршена (Добрушина 2016: 133).

${ }^{23}$ Другим речима, за деонтички императив је карактеристична индиректна адресација (непрямая адресащия в. (Изотов 2007: 198)).

${ }^{24}$ Пример представља модификовану пословицу коју срећемо и у другим језицима, нпр. рус. Дай ему палец, а он всю руку откусит.

${ }^{25}$ Посебна тема, коју овом приликом нећемо детаљније разматрати, јесте питање односа кондиционалног императива и одабраних примера тзв. пословичког или гномског императива попут Пусти добро низ воду, доћи ће ти уз воду (пример из Пипер и др. 2013: 406). С једне стране, овакви сентенцијални изрази могли би се разматрати као примери кондиционалног императива. С друге стране, конструкције са кондиционалним императивом у примерима 30 и 31 , иако представљају начелну тврдњу, немају свевременско гномско значење. 
Кондиционалним императивом ${ }^{26}$ означава се ситуација $S_{1}$ која је реално могућа а чија реализација имплицира актуализацију $\mathrm{S}_{2}: \mathrm{S}_{1} \rightarrow \mathrm{S}_{2}$, те бисмо његово инваријантно значење могли представити овако: 'говорно лице сигнализира да је актуализација ситуације $S_{1}$ услов актуализације ситуације $S_{2}$ ' Ситуација $S_{1}$ je реално могућа, ${ }^{27}$ што потврђује употреба футура I у другом предикацијском делу. Агенс, који може бити било које лице, није вербализован на површинском синтаксичком нивоу, тј. немамо експлициран граматички субјекат (уп. Храковский и др. 2001: 242). Када је пак реч о значењу граматичке категорије вида, у првом предикацијком делу могу бити императивни облици и имперфективних и перфективних глагола, док у другом предикацијском делу чешће срећемо глаголе свршеног вида.

\section{3. Закључак}

Као што се може видети, и наше истраживање је потврдило општепознату чињеницу да непрототипично може бити употребљен само императивни облик за 2. лице једнине, као и то да транспозицијом овај облик губи могућност спојивости са вршиоцем прескрибоване радње који је носилац семантичке улоге Адресата, што је заправо кључни моменат кад говоримо о природи овог језичког феномена.

Међутим, без обзира на неоспорну чињеницу да је непрототипична употреба императивних облика карактеристична за специфично нараторски организован текст (Станојчић 1980: 106), чиме би се могао објаснити термин приповедачки као заједнички именитељ свих разматраних непрототичних употреба императивних облика, чини нам се да је ово истраживање потврдило следеће: разлике на семантичком али и структурном плану отварају могућност разликовања приповедачког, квалификативног, хабитуалног, адмиративног, концесивног, деонтичког и кондиционалног императива.

Наведене непрототичне употребе, односно пренесена значења императивних облика као и њихове основне карактеристике дајемо у следећој прегледној табели.

${ }^{26}$ У зависности од тога да ли једна предикацијска јединица захтева или не захтева обавезно другу предикацијску јединицу С. Танасић разликује имплицитно зависне и имплицитно напоредне асиндентске реченице (Танасић 2018: 602; 608). У складу са том поделом, конструкције са кондиционалним императивом би припадале имплицитно напоредносложеним асиндентским реченицама, што потврђује и запажање И. Прањковића: „Unatoč tome takve strukture treba pribrajati koordiniranima, što se vidi i po tome što se među surečenice takvih struktura može uvrstiti i izrazito kopulativni veznik $i$, usp. Kucajte $\boldsymbol{i}$ otvorit će vam se (Pranjković 2018: 84).

${ }^{27}$ И помоћу императивног облика у његовој прототипичној употреби може се вербализовати нереференцијална радња, штавише нереференцијална „употреба императива чак није спорадична појава у српском језику: постоје одређене прилике кад се редовно императивом исказују радње као нереференцијалне» (Танасић 1996: 28). Слично запажање налазимо и у Нормативној граматици српског језика где се указује на могућност уопштеног значење императивних облика (Пипер и др. 2013: 405). 


\begin{tabular}{|c|c|c|c|c|c|c|}
\hline & & агенс & $\begin{array}{c}\text { граматички } \\
\text { субјекат } \\
\text { може бити } \\
\text { експлициран }\end{array}$ & вид & $\begin{array}{c}\text { претери- } \\
\text { тална } \\
\text { маркира- } \\
\text { ност }\end{array}$ & $\begin{array}{c}\text { инваријантно } \\
\text { значење }\end{array}$ \\
\hline 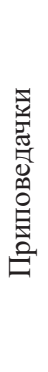 & 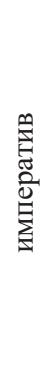 & $\begin{array}{c}\text { говорно или } \\
\text { треће лице }\end{array}$ & $\begin{array}{c}\text { да (1. и 3. лице } \\
\text { оба граматичка } \\
\text { броја) }\end{array}$ & $\begin{array}{c}\mathrm{CB} \text { и } \\
\text { (ређе) } \\
\mathrm{HCB}\end{array}$ & да & $\begin{array}{c}\text { 'говорно лице } \\
\text { сигнализира да је } \\
\text { до актуализације } \\
\text { ситуације } \mathrm{S}_{1}\left(\mathrm{~S}_{2},\right. \\
\ldots) \text { дошло у тре- } \\
\left.\text { нутку } \mathrm{t}_{1} \mathrm{t}_{2}, \ldots\right) ; \\
\left.\text { тренутак } \mathrm{t}_{1} \mathrm{t}_{2}, \ldots\right) \\
\text { претходи тренут- } \\
\text { ку говора' }\end{array}$ \\
\hline 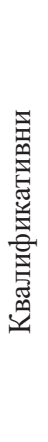 & 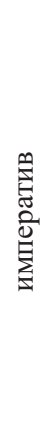 & $\begin{array}{l}\text { углавном } \\
\text { треће лице }\end{array}$ & $\begin{array}{c}\text { да (3. лице } \\
\text { оба граматичка } \\
\text { броја) }\end{array}$ & СВ и НСВ & да & $\begin{array}{c}\text { 'говорно лице } \\
\text { сигнализира да } \\
\text { се током времен- } \\
\text { ског периода, } \\
\text { који је претходио } \\
\text { тренутку гово- } \\
\text { ра, актуализација } \\
\text { ситуације } \mathrm{S}_{1} \\
\text { одвијала нагла- } \\
\text { шеним интензи- } \\
\text { тетом’ }\end{array}$ \\
\hline 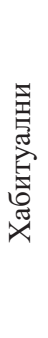 & 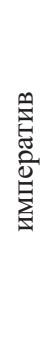 & $\begin{array}{c}\text { углавном треће } \\
\text { али може бити } \\
\text { и говорно лице }\end{array}$ & $\begin{array}{c}\text { да (3. и 1. лице } \\
\text { оба граматичка } \\
\text { броја) }\end{array}$ & $\begin{array}{c}\text { НСВ и } \\
\text { (peђе) СВ }\end{array}$ & да & $\begin{array}{c}\text { 'говорно лице } \\
\text { сигнализира да је } \\
\text { у прошлости на- } \\
\text { кон актуализације } \\
\text { ситуације } \mathrm{S}_{1} \text { сва- } \\
\text { ког пута следи- } \\
\text { ла актуализација } \\
\text { ситуације } \mathrm{S}_{2} \text { ' }\end{array}$ \\
\hline 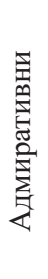 & 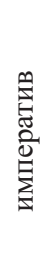 & $\begin{array}{c}\text { говорно или } \\
\text { треће лице }\end{array}$ & $\begin{array}{c}\text { да (1. и 3. лице } \\
\text { оба граматичка } \\
\text { броја) }\end{array}$ & $\mathrm{CB}$ & да & $\begin{array}{c}\text { 'говорно лице } \\
\text { сигнализира } \\
\text { да је у тренут- } \\
\text { ку t дошло до } \\
\text { неочекиване } \\
\text { актуализације } \\
\text { ситуације S' }\end{array}$ \\
\hline
\end{tabular}




\begin{tabular}{|c|c|c|c|c|c|c|}
\hline 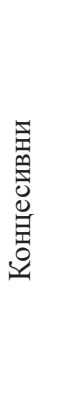 & 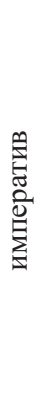 & $\begin{array}{c}\text { било које } \\
\text { лице }\end{array}$ & не & HCB & не & $\begin{array}{c}\text { 'актуелност } \\
\text { ситуације } \mathrm{S}_{1} \text { им- } \\
\text { плицира неакту- } \\
\text { елност ситуције } \\
\mathrm{S}_{2} \text {; говорно лице } \\
\text { констатује акту- } \\
\text { елност ситуације } \\
\mathrm{S}_{1} \text { без обзира на } \\
\text { то што је актуел- } \\
\text { на ситуација } \mathrm{S}_{2},\end{array}$ \\
\hline 绨 & 音 & $\begin{array}{c}\text { говорно } \\
\text { лице }\end{array}$ & $\begin{array}{c}\text { да (заменица } \\
\text { за 2. лице једнине } \\
+ \text { именица у вока- } \\
\text { тиву) }\end{array}$ & HCB & не & $\begin{array}{c}\text { ‘говорно лице } \\
\text { сигнализира да } \\
\text { му се намеће } \\
\text { актуализација } \\
\text { ситуације S ‘ }\end{array}$ \\
\hline 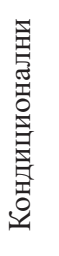 & 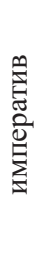 & било које лице & не & $\mathrm{CB}$ & не & $\begin{array}{c}\text { ‘говорно лице } \\
\text { сигнализира да } \\
\text { је актуализација } \\
\text { ситуације } \mathrm{S}_{1} \text { ус- } \\
\text { лов актуализације } \\
\text { ситуације } \mathrm{S}_{2}\end{array}$ \\
\hline
\end{tabular}

На крају бисмо само додали следеће: наш циљ је био да у раду укажемо на основе уочене карактеристике транспозиционих употреба императивних облика, свесни тога да смо се многих питања тек овлаш дотакли.

\section{Цитирана литература}

Ашић, Тијана. «С оне стране потенцијала: нови приступ појашњења употребе потенцијала за означавање понављања у прошлости». Научни састанак слависта у Вукове дане 36/1, Београд: Филолошки факултет, 2007: 137-150.

[Ašić, Tijana. «S one strane potencijala: novi pristup pojašnjenja upotrebe potencijala za označavanje ponavljanja u prošlosti». Naučni sastanak slavista u Vukove dane 36/1, Beograd: Filološki fakultet, 2007: 137-150]

Вежбицкая, Анна. Семантические универсалии и описание языков. Пер. с англ. А. Д. Шмелева под ред. Т. В. Булыгиной. Москва: Языки русской культуры, 1999.

[Vezhbitskaia, Anna. Semanticheskie universalii i opisanie iazykov. Per. s angl. A. D. SHmeleva pod red. T. V. Bulyginoř. Moskva: TAzyki russkoĭ kul'tury, 1999]

Вељовић, Бојана. «Обележавање понављаних прошлих радњи у приповеткама Ћамила Сирајића». Исходишта, Темишвар-Ниш: Савез Срба у Румунији, Universitatea de Vest din Temisoara, Филозофски факултет Универзитета у Нишу, 2017: 45-61. 
[Veljović, Bojana. «Obeležavanje ponavljanih prošlih radnji u pripovetkama Ćamila Sirajića». Ishodišta, Temišvar-Niš: Savez Srba u Rumuniji, Universitatea de Vest din Temisoara, Filozofski fakultet Univerziteta u Nišu, 2017: 45-61]

Вељовић, Бојана, Младеновић Радивоје. «Временска употреба претериталних облика у говору северошарпланинске жупе Сиринић». Јужнословенски филолог LXXIII, св. 3-4, Београд: Институт за српски језик САНУ, 2017: 35-60.

[Veljović, Bojana, Mladenović Radivoje. «Vremenska upotreba preteritalnih oblika u govoru severošarplaninske župe Sirinić». Južnoslovenski filolog LXXIII, sv. 3-4, Beograd: Institut za srpski jezik SANU, 2017: 35-60]

Гусев, Валентин Ю. Типология императива. Москва: Языки славянской культуры, 2013.

[Gusev, Valentin Û. Tipologiîa imperativa. Moskva: IAzyki slavânskor kul'tury, 2013]

Добровольский, Дмитрий, Людмила Пёппель. Корпусное исследование квазисинонимичных конструкций возьми и vimp. vs. взял и v3pers. Anuari de filologia. Llengües i literatures modernes, ISSN-e 2014-1394, №. 8, 2018, págs. 115-131.

[Dobrovol'skiǐ, Dmitriı̌, Liûdmila Pëppel'. Korpusnoe issledovanie kvazisinonimichnykh konstruktșiı̆ voz'mi i vimp. vs. vzial i v3pers. Anuari de filologia. Llengües i literatures modernes, ISSN-e 2014-1394, No .8 , 2018, págs. 115-131]

Добрушина, Нина Р. «Повелительное наклонение». [В:] В. А. Плунгян (отв. ред.) Материалы к корпусной грамматике русского языка. Глагол. Часть 1. СанктПетербург: Издательство Нестор-История, 2016: 161- 212.

[Dobrushina, Nina R. «Povelitel'noe naklonenie». [V:] V. A. Plungian (otv. red.) Materialy k korpusnoř grammatike russkogo iazyka. Glagol. CHast' 1. Sankt-Peterburg: Izdatel'stvo Nestor-Istoriia, 2016: 161-212]

Евтюхин, Вячеслав Б. Специфика значений обусловленности (предикативность, биситуативность, несимметричность). [В:] Бондарко Александр и др. Теория функциональной грамматики. Локативность. Бытийность. Посессивность. Обусловленность. Санкт-Петербург: НАУКА, 1996: 140-142.

[Evtiūkhin, Viācheslav B. Spetșifika znacheniǐ obuslovlennosti (predikativnost', bisituativnost', nesimmetrichnost'). [V:] Bondarko Aleksandr i dr. Teoriiā funktșional'noĭ grammatiki. Lokativnost'. Bytǐnost'. Posessivnost'. Obuslovlennost'. Sankt-Peterburg: NAUKA, 1996: 140-142]

Јањушевић, Ана. Форме са императивним значењем у српском језику. Рукопис магистарске дисертације одбрањене на Филолошком факултету у Београду, 2005.

[Janjušević, Ana. Forme sa imperativnim značenjem u srpskom jeziku. Rukopis magistarske disertacije odbranjene na Filološkom fakultetu u Beogradu, 2005]

Јањушевић, Ана. Интезификаторске партикуле у савременом српском језику. Косовска Митровица-Нишић, 2018.

[Janjušević, Ana. Intezifikatorske partikule u savremenom srpskom jeziku. Kosovska Mitrovica-Nišić, 2018]

Ивић, Милка. Начини на које словенски глагол овремењује понављану радњу. Лингвистички огледи. Београд: Словограф, 1995.

[Ivić, Milka. Načini na koje slovenski glagol ovremenjuje ponavljanu radnju. Lingvistički ogledi. Beograd: Slovograf, 1995]

Изотов, Андрей И. Функционально-семантическая категория императивности в современном чешском языке в сопоставлении с русским. Брно: L.Marek, 2005. <https://www.philol.msu.ru/ slavphil/books/imper.pdf> 14.10.2019. 
[Izotov, Andrel̆ I. Funkţsional'no-semanticheskaîa kategoriâa imperativnosti v sovremennom cheshskom iazyke v sopostavlenii s russkim. Brno: L.Marek, 2005. <https://www.philol.msu.ru/ slavphil/books/imper.pdf> 14.10.2019]

Керкез, Драгана. «Претеритална времена и неочекиваност у српском језику (у поређењу са руским)». Српско језичко насљеђе на простору данашње Црне Горе и српски језик данас. Зборник радова са Међународног научног скупа одржаног у Херцег Новом 20 -23. априла 2012. - Никшић: Матица српска - Друштво чланова у Црној Гори. Одјељење за српски језик и књижвеност, Матица српска у Новом Саду: 459-468.

[Kerkez, Dragana. «Preteritalna vremena i neočekivanost u srpskom jeziku (u poređenju sa ruskim)». Srpsko jezičko nasljeđe na prostoru današnje Crne Gore i srpski jezik danas. Zbornik radova sa Međunarodnog naučnog skupa održanog u Herceg Novom 20 -23. aprila 2012. - Nikšić: Matica srpska - Društvo članova u Crnoj Gori. Odjeljenje za srpski jezik i knjižvenost, Matica srpska u Novom Sadu: 459-468]

Князев, Юрий П. Грамматическая семантика: Русский язык в типологической перспективе, Москва: Языки славянских культур, 2007.

[Kniâzev, IOriĭ P. Grammaticheskaiā semantika: Russkiı̌ iāzyk v tipologicheskoŭ perspektive, Moskva: IAzzyki slaviānskikh kul'tur, 2007]

Манучарян, Иветта К. «Ирреальность в глагольных система славянских языков в синхронии и диахронии». Русский язык и литература в пространстве мировой культуры. Материалы ХІІІ Конгресса МАПРЯЛ. Составители: Н. М. Марусенко, М. С. Шишков. Санкт-Петербург: Издательство Международное некоммерческое партнерство преподавателей русского языка и литературы «МАПРЯЛ». 2015, 178182. <https://www.elibrary.ru/item.asp?id=26432328\&>14.10.2019.

[Manuchariān, Ivetta K. «Irreal'nost' v glagol'nykh sistema slaviānskikh iāzykov v sinkhronii i diakhronii». Russkiǔ iâzyk i literatura v prostranstve mirovoǔ kul'tury. Materialy KHIII Kongressa MAPRIAL. Sostaviteli: N. M. Marusenko, M. S. SHishkov. SanktPeterburg: Izdatel'stvo Mezhdunarodnoe nekommercheskoe partnerstvo prepodavatelě russkogo iāzyka i literatury "MAPRIAL". 2015, 178-182. < https://www.elibrary.ru/item. asp?id=26432328\& $>14.10 .2019]$

Падучева, Елена В. Динамические модели в семантике лексики. Москва: Языки славянской культуры, 2004.

[Paducheva, Elena V. Dinamicheskie modeli v semantike leksiki. Moskva: IAzyki slaviānskoĭ kul'tury, 2004]

Перцов, Николай В. Инварианты в русском словоизменении. Москва: Языки русской культуры, 2001.

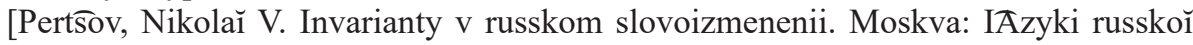
kul'tury, 2001]

Пешикан, Митар. О неким специфичностима у употреби приповедачког императива, Наш језик. Нова серија. Књига VII, св. 5-6, Београд: Српска академија наука. Институт за српски језик, 1956: 153-166.

[Pešikan, Mitar. O nekim specifičnostima u upotrebi pripovedačkog imperativa, Naš jezik. Nova serija. Knjiga VII, sv. 5-6, Beograd: Srpska akademija nauka. Institut za srpski jezik, 1956: 153-166]

Пипер, Предраг, Иван Клајн. Нормативна граматика српког језика. Нови Сад: Матица српска, 2013.

[Piper, Predrag, Ivan Klajn. Normativna gramatika srpkog jezika. Novi Sad: Matica srpska, 2013] 
Ракић-Милојковић, Софија. Синтаксички упитник за говоре косовско-ресавске и призренско-тимочке дијалекатске зоне, Српски дијалектолошки зборник XLI. Расправе и грађа. Главни уредник Павле Ивић. Београд: Српска академија наука и уметности и Институт за српски језик, 1995: 521-570.

[Rakić-Milojković, Sofija. Sintaskički upitnik za govore kosovsko-resavske i prizrensko-timočke dijalekatske zone, Srpski dijalektološki zbornik XLI. Rasrpave i gradja. Glavni urednik Plavle Ivić. Beograd: Srpska akademija nauka i umetnosti i Institut za srpski jezik, 1995: 521-570]

Св. Јован Дамаскин. Источник знања. Београд: Јасен, 2006.

[Sv. Jovan Damaskin. Istočnik znanja. Beograd: Jasen, 2006]

Станојчић, Живојин. Стинтакса језика Лазе К. Лазаревића. II Речнички односи. Београд: Институт за српскохрватски језик, 1980.

[Stanojčić, Živojin. Stintaksa jezika Laze K. Lazarevića. II Rečnički odnosi. Beograd: Institut za srpskohrvatski jezik, 1980]

Станојчић, Живојин, Поповић Љубомир. Граматика српског језика. Уџбеник за I, II, III и IV разред средње школе. Друго, прерађено издање. Београд - Нови Сад: Завод за уџбенике и наставна средства - Завод за издавање уџбеника, 1992.

[Stanojčić, Živojin, Popović Ljubomir. Gramatika srpskog jezika. Udžbenik za I, II, III i IV razred srednje škole. Drugo, prerađeno izdanje. Beograd - Novi Sad: Zavod za udžbenike i nastavna sredstva - Zavod za izdavanje udžbenika, 1992.

Стевановић, Михаило. «Глаголски облици као међусобне синтаксичке опозиције». Јужнословенски филолог, Књига XXIX, св. 1-2, 1971, стр. 81-103.

[Stevanović, Mihailo. «Glagolski oblici kao međusobne sintaksičke opozicije». Južnoslovenski filolog, Knjiga XXIX, sv. 1-2, 1971, str. 81-103]

Стевановић, Михаило, Савремени српскохрватски језик II, Београд: Научна књига, 1989.

[Stevanović, Mihailo, Savremeni srpskohrvatski jezik II, Beograd: Naučna knjiga, 1989]

Стојановић, Љубомир. «О значењу и употреби глаголских облика у реченицама». Јужнословенски филолог. Повремени спис за словенску филологију и лингвистику, Књига II, св. 2-3, Београд, 1921.

[Stojanović, Ljubomir. «O značenju i upotrebi glagolskih oblika u rečenicama». Južnoslovenski filolog. Povremeni spis za slovensku filologiju i lingvistiku, Knjiga II, sv. 2-3, Beograd, 1921]

Фортейн, Эгберт. «Полисемия императива в русском языке». Вопросы языкознания. №1, Москва: Российская академия наук, 2008: 3-24.

[Forteĭn, Ėgbert. «Polisemiiā imperativa v russkom iâzyke». Voprosy iâzykoznaniiā. №1, Moskva: Rossiǔskaiā akademiiā nauk, 2008: 3-24.]

Храковский, Виктор С., Александар П. Володин. Семантика и типология императива: Русский императив. Отв. ред. В. Б. Касевич. Изд. 2-е, стереотипное. Москва: Едиториал УРСС, 2001.

[Xrakovskiū, Viktor S., Aleksandar P. Volodin. Semantika i tipologiiā imperativa: Russkiı̌ imperativ. Otv. red. V. B. Kasevich. Izd. 2-e, stereotipnoe. Moskva: Editorial URSS, 2001.]

Харковский, Виктор С. Типология итеративных конструкций. Отв. ред. В.С. Храковский. Ленинград: «НАУКА» Ленинградское отделение, 1989.

[Xarkovskiı̌, Viktor S. Tipologiia iterativnykh konstruktsiı̌. Otv. red. V.S. Xrakovskiı̌. 
Leningrad: «NAUKA» Leningradskoe otdelenie, 1989.]

Танасић, Срето. Презент у савременом српском језику. Београд: Институт за српски језик САНУ, 1996.

[Tanasić, Sreto. Prezent u savremenom srpskom jeziku. Beograd: Institut za spski jezik SANU, 1996]

Танасић, Срето. Глаголски начини. Императив. [В:] Пипер, Предраг, Ивана Антовић, Владислава Ружић, Срето Танасић, Људмила Поповић, Бранко Тошовић. Синтакса српског језика. Проста реченица. У редакцији академика Милке Ивић. Београд: Институт за српски језик САНУ, Београдска књига, Матица српска: 2005: 453-457.

[Tanasić, Sreto. Glagoslki načini. Imperativ. [V:] Piper, Predrag, Ivana Antović, Vladislava Ružić, Sreto Tanasić, Ljudmila Popović, Branko Tošović. Stintaksa srpskog jezika. Prosta rečenica. U redakciji akedemika Milke Ivić. Beograd, Institut za srpski jezik SANU, Beogradska knjiga, Matica srpska, 2005: 453-457]

Танасић, Срето. «Асиндентске реченице». [В:] Пипер, Предраг, Миливоје Алановић, Слободан Павловић, Ивана Антонић, Марина Николић, Дојчил Војводић, Људмила Поповић, Срето Танасић, Биљана Марић. Синтакса сложене реченице у савременом српском језику. У редкацији Предрага Пипера. Нови Сад: Матица српска: Институт за српски језик САНУ, 2018: 597-633.

[Tanasić, Sreto. «Asindentske rečenice». [V:] Piper, Predrag, Milivoje Alanović, Slobodan Pavlović, Ivana Antonić, Marina Nikolić, Dojčil Vojvodić, Ljudmila Popović, Sreto Tanasić, Biljana Marić. Sintaksa složene rečenice u savremenom srpskom jeziku. U redkaciji Predraga Pipera. Novi Sad: Matica srpska: Institut za srpski jezik SANU, 2018: 597-633]

Томановић, Васо. «О значењима императива». Годишен зборник НА Филозофскиот факултет на Скопје, књ.13, 1963: 223-228.

[Tomanović, Vaso. «O značenjima imperativa». Godišen zbornik NA Filozofskiot fakultet na Skopje, knj.13, 1963: 223-228]

Томаселло, Майкл. Истоки человеческого общения. Пер. с англ. М.В. Фаликман, Е.В. Печенковой, М.В. Синицыной, Анны А. Кибрик, А.И. Карпухиной. Москва: Языки славянских культур, 2011.

[Tomasello, Maǐkl. Istoki chelovecheskogo obshcheniiā. Per. s angl. M.V. Falikman,

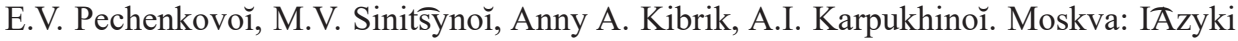
slaviānskikh kul'tur, 2011]

Цейтлин, Стелла Н. Язык и ребенок: Лингвистика детской речи: Учеб. пособие для студ. высш. учеб. заведений. Москва: Гуманит. изд. центр ВЛАДОС, 2000.

[TSeĭtlin, Stella N. IAzyk i rebenok: Lingvistika detskor rechi: Ucheb. posobie dliā stud. vyssh. ucheb. zavedeniǐ. Moskva: Gumanit. izd. ţ̄entr VLADOS, 2000]

Шведова, Наталья Ю. «Средства формирования и выражения субъективно-модальных значений». [В:] Н. Ю. Шведова (гл. ред.). Русская грамматика II: Синтаксис. Москва: Наука, 1980: 214-231. (Институт русского языка АН СССР)

[SHvedova, Natal'iā IO. «Sredstva formirovaniiā i vyrazheniiā sub"ektivnomodal'nykh znacheniǐ». [V:] N. IU. SHvedova (gl. red.). Russkaiā grammatika II: Sintaksis. Moskva: Nauka,1980: 214-231. (Institut russkogo iāzyka AN SSSR)]

Шлуинский, Андрей Б. Типология предикатной множественности: количественные аспектуальные значения. Диссертация на соискание ученой степени кандидата филологических наук. Москва: 2005. <https://iling-ran.ru/Shluinsky/ashl/ TipologijaPredikatnoj_2005_disser.pdf $>$ 24.01.2018. 
[SHluinskiı̌, Andrě̌ B. Tipologiiā predikatnoĭ mnozhestvennosti: kolichestvennye aspektual'nye znacheniiā. Dissertatșiiā na soiskanie uchenoř stepeni kandidata filologicheskikh nauk. Moskva: 2005. https://iling-ran.ru/Shluinsky/ashl/Tipologija Predikatnoj_2005_disser.pdf 24.01.2018]

Minović, Milivoje. Sintaksa srpskohrvatskog - hrvatskosrpskog književnog jezika za više škole. Rečenica, padeži, glagolski oblici. Sarajevo: „Svjetlost“. OOUR, Zavod za udžbenike i nastavna sredstva, 1987.

Pranjković, Ivo. «Glagolski načini u složenim rečenicama». Sarajevski filološki susreti 4: Zbornik radova (knj. 1). Palić, Ismail (ur.). Sarajevo: Bosansko filološko društvo, 2018. str. 82-88. <https://www.academia.edu/37615806/Glagolski_načini_u_složenim_ rečenicama>

\section{Извори}

CK: Корпус савременог српског језика <www. korpus.matf.bg.ac.rs>

[SK: Korpus savremenog srpskog jezika <www. korpus.matf.bg.ac.rs $>$ ]

КЛ: Корпус српског језика $<$ https://www.clarin.si/>

[KL: Korpus srpskog jezika $<$ https://www.clarin.si/>]

СРБ-У: $<$ http://srb.ucioogle.rs/str.aspx?id $>$

[SRB-U: $<$ http://srb.ucioogle.rs/str.aspx?id $>$ ]

Југпрес: <https://jugpress.com/slucaj-radomira-stanojevica/ >

[Jugpres: < https://jugpress.com/slucaj-radomira-stanojevica/ > ]

ППњ_ГВ_АСК: Петар Петровић Његош, Горски вијенац.

$<$ www.antologijasrpskeknjizevnosti.rs $>$

[PPNj_GV_ASK:PetarPetrovićNjegoš, Gorskivijenac.<www.antologijasrpskeknjizevnosti.rs $>$ ]

Глиш_ACК: Милован Глишић, Приповетке. <www.antologijasrpskeknjizevnosti.rs>

[Gliš_ASK: Milovan Glišić, Pripovetke. <www.antologijasrpskeknjizevnosti.rs>]

СрпНП_АСК: Српске народне приповетеке. <www.antologijasrpskeknjizevnosti.rs>

[SrpNP_ASK: Srpske narodne pripoveteke. <www.antologijasrpskeknjizevnosti.rs>]

ОрлЋоп_АСК: Бранко Ћопић, Орлови рано лете. <www.antologijasrpskeknjizevnosti.rs>

[OrlĆop_ASK: Branko Ćopić, Orlovi rano lete. <www.antologijasrpskeknjizevnosti.rs>]

ПопСр_АСК: Стеван Сремац, Поп Ћира и поп Спира. <www. antologijasrpskeknjizevnosti.rs>

[PopSr_ASK:StevanSremac,PopĆiraipopSpira. $<$ www.antologijasrpskeknjizevnosti. rs $>$ ]

Нуш_ГМ_АСК: Бранислав Нушић, Госпођа министарка. <www.antologijasrpskeknjizevnosti.rs>

[Nuš_GM_ASK: Branislav Nušić, Gospođa ministarka. <www. antologijasrpskeknjizevnosti.rs> ] 
Драгана Керкез

\author{
ПЕРЕНОСНОЕ УПОТРЕБЛЕНИЕ ФОРМ \\ ПОВЕЛИТЕЛЬНОГО НАКЛОНЕНИЯ В СЕРБСКОМ ЯЗЫКЕ
}

\begin{abstract}
Резюме
Статья посвящена тем переносным употреблениям форм императива в сербском языке, которые в существующей литературе на сербском языке принято называть драматическими (серб. приповедачки императив). На основе анализа структурных и семантических особенностей автор выделяет две группы внепарадигматических непрямых употреблений императивных форм. В первую группу входят те переносные употребления императивных форм, которые указывают на действие имеющее место в прошлом (драматический императив (серб. приповедачки), императив характеризации (серб. квалификативни), хабитуальный императив (серб. хабитуални), адмиративный императив (серб. адмиративни). Вторую группу составили переносные употребления императивных форм, которые не являются маркированными по отношению к категории претеритальности (императив долженствования (серб. деонтички), императив уступки (серб. концесивни), императив условия (серб. кондиционални).

Ключевые слова: переносное значение, прошлое, драматический императив, структурносемантический, лицо, грамматическое число.
\end{abstract}

